University of South Florida

DIGITAL COMMONS

Digital Commons @ University of

@ UNIVERSITY OF SOUTH FLORIDA

South Florida

$12-2011$

\title{
Observations of Brachygnathia Superior (Underbite) in Wild Ruminates in Western Montana, USA
}

J. A. Hoy

Bitterroot Wildlife Rehab Center

G. T. Haas

Big Sky Beetle Works

R. D. Hoy

Bitterroot Wildlife Rehab Center

Pamela Hallock

University of South Florida, pmuller@usf.edu

Follow this and additional works at: https://digitalcommons.usf.edu/msc_facpub

Part of the Life Sciences Commons

\section{Scholar Commons Citation}

Hoy, J. A.; Haas, G. T.; Hoy, R. D.; and Hallock, Pamela, "Observations of Brachygnathia Superior (Underbite) in Wild Ruminates in Western Montana, USA" (2011). Marine Science Faculty Publications. 927.

https://digitalcommons.usf.edu/msc_facpub/927

This Article is brought to you for free and open access by the College of Marine Science at Digital Commons @ University of South Florida. It has been accepted for inclusion in Marine Science Faculty Publications by an authorized administrator of Digital Commons @ University of South Florida. For more information, please contact digitalcommons@usf.edu. 


\title{
ORIGINAL PAPER
}

\section{Observations Of Brachygnathia Superior In Wild Ruminants In Western Montana, Usa}

\author{
J.A. Hoy ${ }^{1}$, G.T. Haas ${ }^{2}$, R.D. Hoy ${ }^{1}$ \& P. Hallock ${ }^{3, *}$
}

1 Bitterroot Wildlife Rehab Center, 2858 Pheasant Lane, Stevensville, Montana 59870, USA. E-mail: bjhoy@localnet.com

2 Big Sky Beetle Works, 5189 Highway 93 South, Florence, Montana 59833, USA.

3 College of Marine Science, University of South Florida, 140 Seventh Avenue S., St. Petersburg, FL 33701-5016 USA.

* Corresponding author e-mail: pmuller@marine.usf.edu

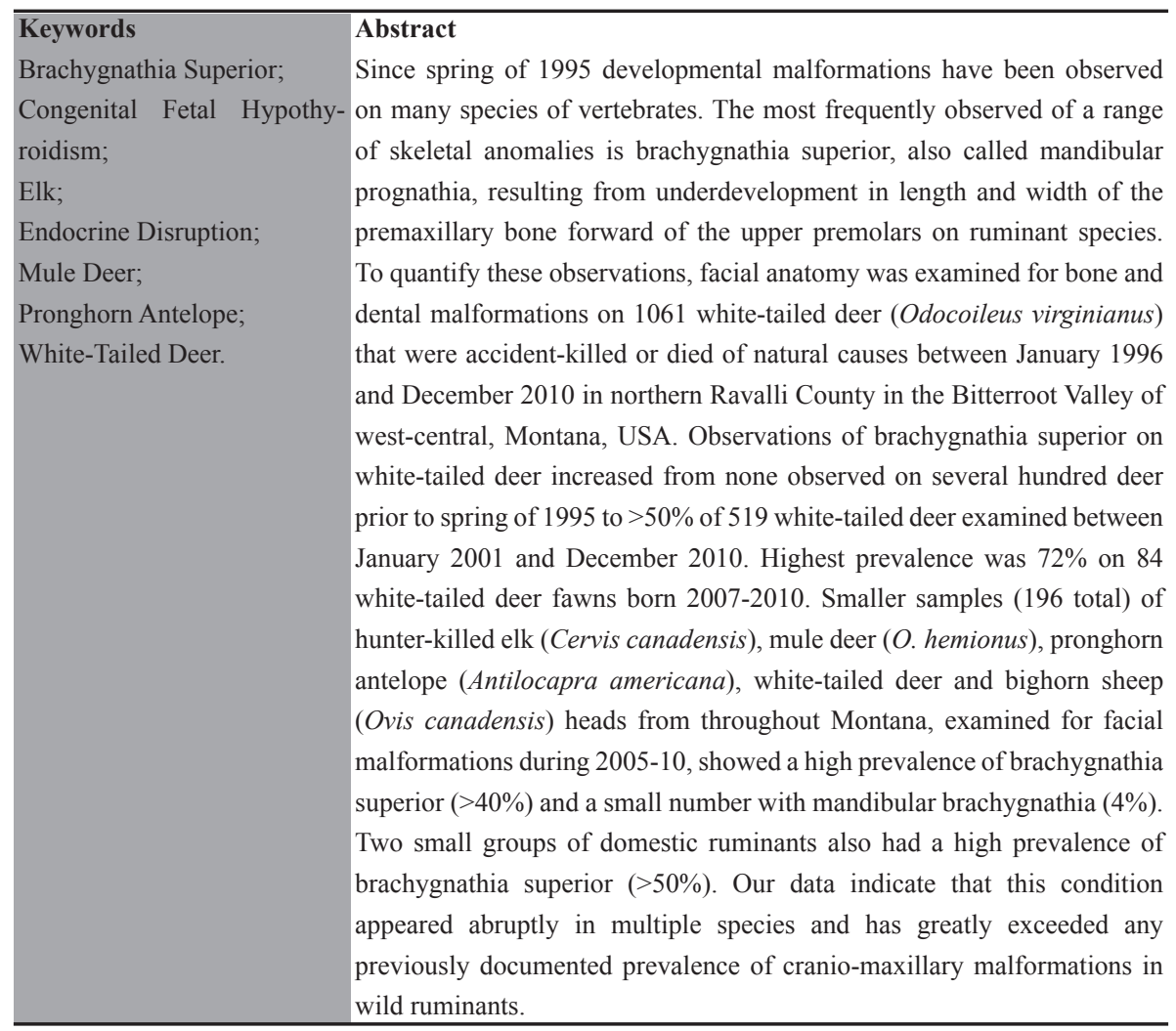

\section{Introduction}

Since 1995, we have observed an unprecedented increase in the prevalence of brachygnathia superior in multiple vertebrate species in Ravalli County (RC) and throughout Montana, in the northwestern USA. Brachygnathia superior is also referred to as mandibular prognathism or underbite [1-3], although the first term is considered 
most correct [4,5]. Mandibular brachygnathia, which is also known as brachygnathia inferior and commonly called parrot mouth or overbite, is characterized by failure of the anterior of the lower jaw forward of the premolars to grow to normal length. The latter abnormality has been observed on ungulate species from other areas of Montana at a higher frequency than on those from RC.

Brachygnathia superior is characterized by failure of the premaxillary bone to grow to normal length and width, and has been reported to be a definitive sign of functional disruption of the fetal thyroid hormones in equine neonates $[1-3,6]$. Aside from studies concerning the disruption of thyroid hormone function during development [1-9], there is little information in the literature on cranio-maxillary underdevelopment. Most importantly, no papers reporting brachygnathia superior on adult wild ruminants were found, indicating that historically, this malformation was seldom observed in studied populations.

Wild and domestic animals are often sentinels for environmental problems that are also affecting humans [9]. Brachygnathia superior and other developmental malformations commonly associated with fetal thyroid dysfunction are increasing in domestic mammals $[1,5,7]$. Similar problems are being increasingly reported in bird species [10-13]. A variety of causal factors, most commonly radiation, malnutrition and manufactured hormone-disrupting chemicals, are widely known to alter the expression of thyroid-hormone-responsive genes. Well-regulated thyroid hormone is also essential for normal brain development in vertebrates, including humans $[14,15]$.

While congenital hypothyroidism is implicated as causing brachygnathia superior and other observed malformations in foals [6], we were unable to test for thyroid function. All data collection or other work done for this paper was a public service, with no funding available for testing. However, we have examined multiple individual newborns of wild and domestic ungulates with two or more of the signs listed for congenital hypothyroidism, nearly always including brachygnathia superior.

Observations of multiple unique abnormalities on accident-killed white-tailed deer, beginning in summer 1995, were so novel that the lead author began to photographically and morphometrically document them. The original focus was on quantifying genital malformations and abnormal sex ratios [16]. On carcasses sufficiently intact for necropsy, if other anomalies or unusual features were observed, they were also recorded. Because facial malformations also were observed at increasing frequency, malformations of the upper and lower mandibles were quantified.

Because most members of our team have been working with wildlife in western Montana for 40 years or more, those individuals have had the opportunity to examine thousands of ungulates and other vertebrates, both dead and alive, over that time. Between 1979 and 2000, one of us (RDH) collected and disposed of accident-killed white-tailed deer, mule deer and elk, typically several hundred animals per year, from area roadsides as one of his responsibilities as a Warden (now retired) for the State of Montana Department of Fish, Wildlife and Parks (MFWP). The lead author, a wildlife rehabilitator, dissected many of the intact accident-killed animals each year after 1979 to use for food for carnivores at their wildlife rescue center and some carcasses were examined where they were found. Also as a public service for MFWP, the lead author cared for several fawns per year of both deer species and five elk calves between 1979 and 2003, all closely examined upon arrival. 
In 1998, another author (GTH), a professional taxidermist who cleans and prepares game animal heads, began observing facial anomalies on wild ruminants. Because of timing and similarity in malformations observed, we subsequently began working together. Between 2005-2010, heads of hunter-killed wild ruminants were examined for brachygnathia superior and mandibular brachygnathia. We here report our observations of a high prevalence of brachygnathia superior from 1996 through 2010 on individuals of multiple ruminant species from Ravalli County and from throughout Montana, USA.

\section{Materials and Methods}

\section{Study Area}

The primary study area: northern Ravalli County, Montana, USA, $6185 \mathrm{~km}^{2}$ in extent, is centered between the northern and southern state lines in the western portion of the state. Encounters with vehicles, fences or dogs provided the accidentkilled deer that were examined. Butchered beef (Bos taurus) heads and live newborn goats (Capra hircus) examined were also from northern RC. In addition, heads of hunter-killed animals harvested throughout Montana, an area covering approximately 381,000 square kilometers, were examined for facial malformations.

\section{Collection of Data}

For a fourteen-year period beginning in January 1996 and ending in December 2010, white-tailed deer that were accident-killed or had been euthanized due to injuries were examined post-mortem for evidence of facial bone malformations (Fig. 1). Age, sex, date of examination, and several body measurements were recorded for each. The year of birth was determined by examining tooth eruption [17]. With both year of birth and day of death (+/- 2 days) known, age determination was accurate to within two months. From 1999-2010, to quantify degree of facial malformations, the distance between the anterior terminus of the maxillary pad and the top edge of the central lower incisors was measured in millimeters on undamaged heads (Fig. 1d). Measurements of normal bites are recorded as negative values, reflecting that the incisors contacted the maxillary pad behind the anterior terminus.

Heads of harvested game animals received from hunters were examined for anomalies by GTH prior to removal of soft tissue. During the 2005-10 hunting seasons, elk (48), mule deer (48) and pronghorn antelope (52) heads were examined. Hunter-killed white-tailed deer (29) were included in 2007-10. Cleaned skulls of adult male bighorn sheep (19) were examined in fall 2010. The presence of underbite (brachygnathia superior), overbite (mandibular brachygnathia) or normal bite was recorded. Year of birth was not determined. The majority of the animals were adult males, 1.5-6.5 years old.

On many newborn animals examined, even when the first lower incisors occluded against the maxillary dental pad indicating that the premaxillary bone was normal in length, the premaxillary bone and thus the dental pad were distinctly narrower than the incisors (Fig. 1b). Because the dental pad is typically wider than the incisors (Fig. 1a) on ruminants [18], the width across the anterior of the premaxillary dental pad where 
the lower incisors normally contact (Fig. 1a) was measured to compare with the measurement taken of the width of the lower incisors from the outside edge of the canine on the left to the outside edge of the canine on the right on available adult and juvenile white-tailed deer, as well as adult antelope, mule deer, and bighorn sheep during 2006-2010.

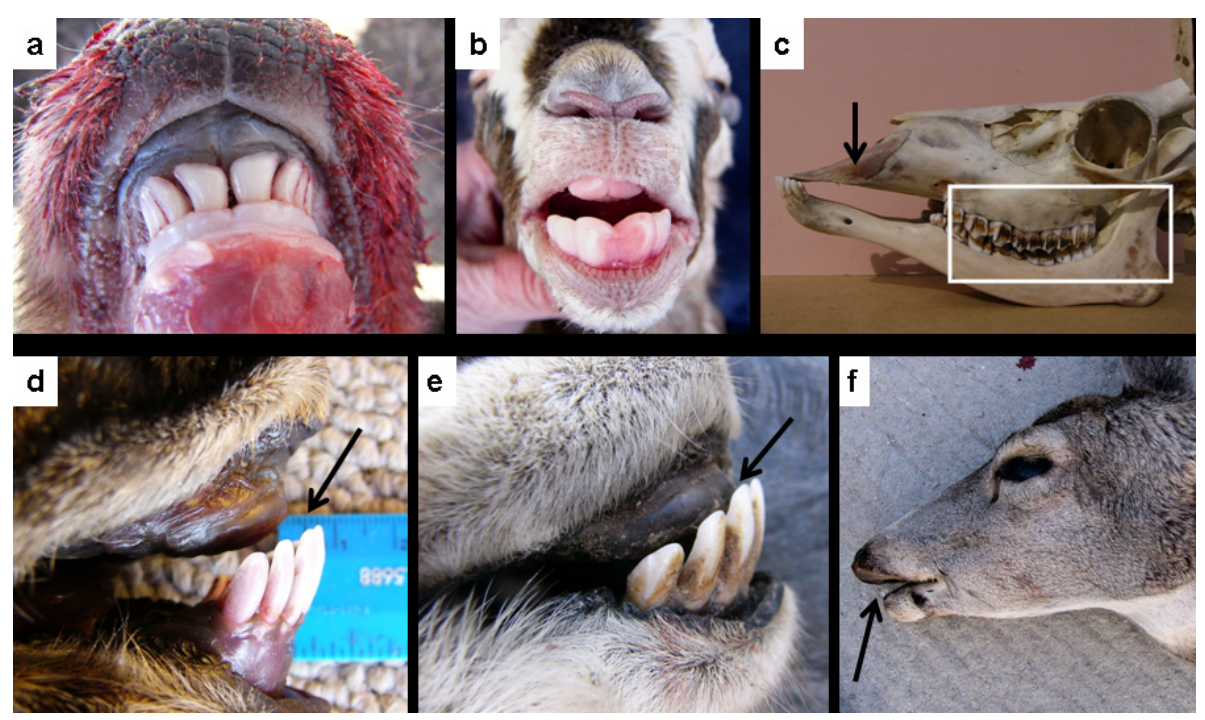

Fig. 1: Examples of normal bite (a), brachygnathia superior (b-e) and mandibular brachygnathia (f) in ungulates from Montana: a. Front view of a female white-tailed deer fawn, with incisors contacting the premaxillary pad. b. Front view of a newborn goat showing narrow premaxillary pad in relationship to the lower incisors. c. Side view of the skull of male white-tailed deer showing the molars in proper alignment (box) and short premaxillary bone (arrow). d. Arrow indicates the distance from the anterior edge of the premaxillary pad to the top edge of the middle incisors of a 3.5 year-old male hunter-killed mule deer. e. Mouth of an adult male pronghorn antelope showing brachygnathia superior (arrow) and premaxillary pad narrower than the incisors. f. Hunter-killed female mule deer from near Miles City, MT, with a short lower jaw (mandibular brachygnathia) (arrow).

Additionally, the following features were checked on whole carcasses: the conjunctiva for blepharitis, the teeth, limbs and hooves for anomalies, and on those necropsied, the heart for enlarged right ventricle and for dilated lymphatic vessels on the surface. However, as those conditions are more difficult to quantify, they are only discussed as ancillary observations.

Two other small data sets were collected in 2009. Thirteen heads of 1.5 year-old butchered male beef (Bos taurus) and 20 newborn domestic goats (Capra hircus) of multiple breeds also were examined for presence or absence of facial malformations.

\section{Results}

Odocoileus virginianus fawns (337) born in Ravalli County in spring of 1995 through spring of 2000 exhibited an average prevalence of brachygnathia superior of 5\% (Table 1). Prevalence sharply increased beginning in 2001 (Fig. 2), with prevalence 
averaging 52\% on 330 fawns between spring 2001 and December 2010 (Table 1). The period of highest occurrence of brachygnathia superior in the 15 years of study began in spring 2007, with an average of 72\% on 84 fawns born 2007-2010. On 394 adult accident-killed $O$. virginianus examined, brachygnathia superior was found on $13 \%$ from 1996-2000 and on 47\% from 2001-2010. Mandibular brachygnathia was present on only 6 of $1061(<1 \%)$ RC O. virginianus examined (Table 1).

Table 1: Prevalence of facial malformations on multiple species of Montana ruminants (\# Exam. = number examined; Malform. = malformations; $\% \mathrm{BS}=$ percent exhibiting brachynathia superior; $\% \mathrm{MB}=$ percent exhibiting mandibular brachynathia).

\begin{tabular}{|c|c|c|c|c|c|c|c|c|c|}
\hline Species & Year Exam. & Sex & Age Class & Area & \# Exam. & \# Jaw Malform. & \% Normal & $\% \mathbf{B S}$ & $\% \mathrm{MB}$ \\
\hline O. virginianus & $1996-2000$ & $\mathrm{~F}$ & Fawn & $\mathrm{RC}$ & 146 & 5 & 97 & 3 & 0 \\
\hline O. virginianus & $2001-2010$ & $\mathrm{~F}$ & Fawn & $\mathrm{RC}$ & 146 & 75 & 49 & 50 & 1 \\
\hline O. virginianus & $1996-2000$ & M & Fawn & $\mathrm{RC}$ & 191 & 12 & 94 & 6 & 0 \\
\hline O. virginianus & $2001-2010$ & M & Fawn & $\mathrm{RC}$ & 184 & 99 & 46 & 53.5 & 0.5 \\
\hline O. virgininunts & $1996-2000$ & M-F & Adult & $\mathrm{RC}$ & 205 & 26 & 87 & 12.5 & 0.5 \\
\hline O. virginianus & $2001-2010$ & $M-F$ & Adult & MT & 189 & 89 & 53 & 46 & 1 \\
\hline O. virginianus & $2005-2010$ & M & H-K Adult & MT & 29 & 14 & 52 & 38 & 10 \\
\hline O. hemionus & $2005-2010$ & M & H-K Adult & MT & 48 & 36 & 25 & 67 & 8 \\
\hline A. americana & $2005-2010$ & M & H-K Adult & MT & 52 & 38 & 27 & 56 & 17 \\
\hline C. canadensis & $2005-2010$ & M & H-K Adult & MT & 48 & 21 & 56 & 31 & 13 \\
\hline O. canadensis & Fall 2009 & M & H-K Adult & MT & 19 & 10 & 47 & 53 & 0 \\
\hline C. hircus & Spring 2009 & M & Newborns & $\mathrm{RC}$ & 20 & 20 & 0 & 100 & 0 \\
\hline B. taurus & Fall 2009 & M & $1 \frac{1}{1 / 2} \mathrm{yr}$ & $\mathrm{RC}$ & 13 & 9 & 31 & 69 & 0 \\
\hline Total examined & All Years & M-F & All & MT & 1290 & 454 & 65 & 31 & 4 \\
\hline
\end{tabular}

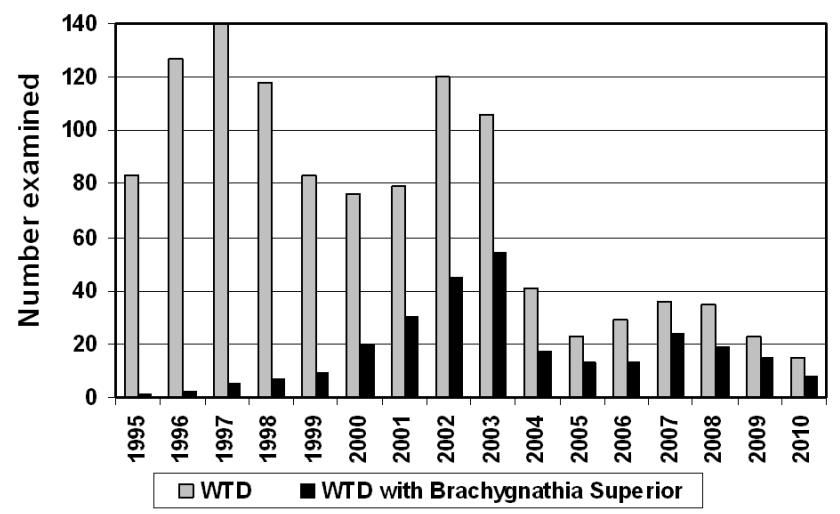

Fig. 2: Number of white-tailed deer (WTD) examined and the number of those that exhibited brachygnathia superior, by year of birth.

On RC O. virginianus specimens exhibiting brachygnathia superior for which the measurement between the anterior terminus of the premaxillary pad and the top of the lower incisors was possible, that offset ranged from 0 and $8 \mathrm{~mm}$. Because that distance also varies with age, only data from undamaged heads of 413 fawns examined between 1999 and 2010 were statistically analyzed. Those data were tested for differences 
between males and females using single-factor analysis of variance (ANOVA), with results indicating no significant difference $(\mathrm{p}=0.40)$. The fawns of both sexes were then pooled by year and tested using ANOVA, revealing highly significant differences across years $(\mathrm{P}=0.00015)$. The means and standard errors were calculated and plotted by year (Fig. 3), with the linear regression revealing a significant increase over the study period, despite substantial inter-annual variability.

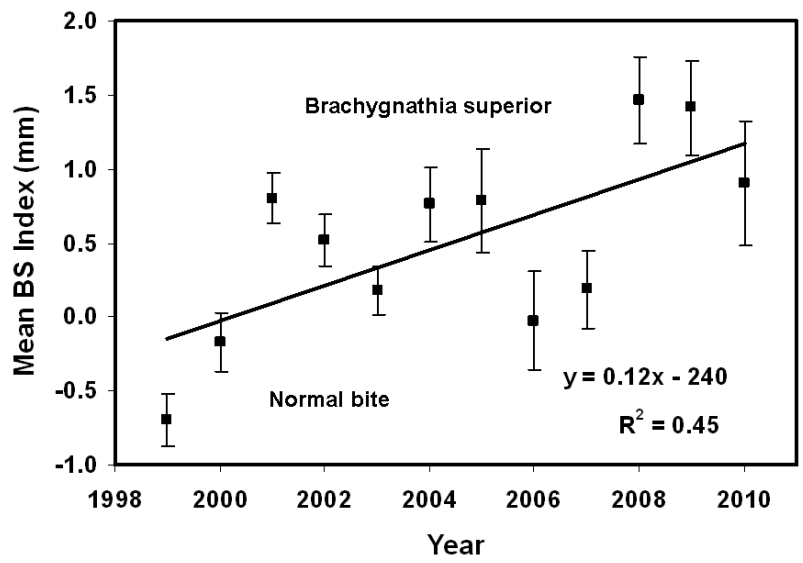

Fig. 3: Results of measurements from undamaged heads of 413 fawns of the distance between the anterior terminus of the premaxillary pad and the top of the first lower incisors [Mean BS (brachygnathia superior) Index]; negative values indicate normal bite. Means with standard error bars for data collected between 1999 and 2010 are shown, as is the linear regression and associated values.

The smaller data sets, including hunter-killed $O$. virginianus, O. hemionus, $C$. canadensis, A. americana and Ovis canadensis, in addition to butchered male $B$. taurus and newborn $C$. hircus, further demonstrate that brachygnathia superior is remarkably prevalent in multiple ruminant species from throughout Montana (Table 1). Moreover, $c a$ three-quarters of the heads examined exhibited incisors that extended laterally beyond the width of the premaxillary pads (Table 2).

Table 2: Observations of wild ungulates species found with incisors extending laterally beyond the width of the premaxillary pad (2006-10).

\begin{tabular}{llcccc}
\hline Species & Age Class & Number Examined & $\begin{array}{c}\text { Wider Incisors } \\
(\mathbf{\%})\end{array}$ & $\begin{array}{c}\text { Wider Premax. Pad } \\
(\mathbf{\%})\end{array}$ & $\begin{array}{c}\text { Equal in width } \\
(\mathbf{\%})\end{array}$ \\
\hline A. americana & Adults & 11 & 82 & 9 & 9 \\
O. hemionus & Adults & 10 & 80 & 0 & 20 \\
O. virginianus & Adults & 26 & 77 & 19 & 4 \\
O. virginianus & Fawns & 82 & 74 & 16 & 10 \\
O. canadensis & Adults & 19 & 68 & 21 & 11 \\
Total examined & All & 129 & 76 & 15 & 9 \\
\hline
\end{tabular}

Blepharitis of the conjunctiva was seasonally present in northern RC on many of the examined $O$. virginianus and $O$. hemionus. Tests of the conjunctiva of several deer by Alpha Veterinary Laboratory, Hamilton, MT, showed no viral or bacterial infection, 
indicating an airborne irritant. Between 2007 and 2010, enlarged right ventricle of the heart, dilated lymphatic vessels on the heart's surface and thymic underdevelopment were noted more often than in previous years during necropsy of fawns.

\section{Discussion}

The prevalence of brachygnathia superior on ruminant species we are reporting is far higher than has previously been reported (to our knowledge) for a bone malformation in a wild mammal population and likely greater than previously found in any ruminant species [19]. From 1959-1961, an extensive study of facial bones, teeth and other malformations in a large sample of 39,027 O. virginianus in Michigan reported no brachygnathia superior [20]. Even in a severely inbred herd of whitetailed deer, the occurrence of 6 fawns exhibiting brachygnathia inferior, representing $6 \%$ of the fawns born over an 11-year period, was considered unusual [21]. Though easily recognized and called underbite by livestock owners, the condition has not been widely reported in Montana for political and economic reasons, even though it has become a common abnormality on both wild and domestic grazing animals.

Mandibular brachygnathia was found on individuals of four species of hunter-killed ruminants at a higher prevalence than the $<0.2 \%$ reported on Michigan $O$. virginianus [20]. Facial malformations and the associated reproductive malformations on ruminant species appear to be a recent phenomenon, uncommon in Montana prior to 1995. In a report on 100 O. virginianus adults and 32 fetuses examined from our study area in 1992, none were found with brachygnathia superior, mandibular brachygnathia or other malformation [22]. The increase in both prevalence (Fig. 2) and degree (Fig. 3 ) of brachygnathia superior, as well as the interannual variability found in our data, implicate an environmental cause that is generally increasing but that varies from year to year.

Brachygnathia superior has primarily been reported from studies of newborn ungulates suffering from naturally or experimentally induced congenital hypothyroidism [6-8,23-25], as are the associated genital abnormalities [16] and other malformations and conditions $[3,6,23,25]$ we found on RC ungulates. Most animals with one or more of the other signs consistent with congenital hypothyroidism also had brachygnathia superior [1-3,6,7]. Many of those abnormalities cause mortality at or soon after birth $[1,6]$, so are not easily observed on wild newborns and are seldom found on adult animals. Neither brachygnathia superior nor maxillary brachygnathia commonly cause mortality postnatally, so they can be observed on individuals of both sexes and all age groups. However, facial malformations likely compromise feeding efficiency and therefore increase probability for starvation during winter or prolonged drought in wildlife, and may reduce growth rates in domestic animals.

Moreover, experimental research has revealed that malnourished domestic sheep produced offspring with compromised thyroid function [24]. The lead author (unpublished) has observed brachygnathia superior in the offspring of malnourished domestic goats. Thus, one can postulate that pregnant female wild ruminants whose offspring have been similarly affected may not have been able to procure sufficient nutrition to support themselves and their fetal young during the winter. Moreover, 
inadequate nutrition, with consequent mineral deficiency, would likely enhance the effects of exposures to hormone-disrupting environmental toxins on a fetus's development and growth [24,25].

In addition to the mammals observed with bone malformations in western Montana, numerous individuals of wild bird species with brachygnathia superior and a variety of limb and feather malformations have been documented photographically by the lead author (unpublished) and others. Similar bill malformations have been reported on avian species from other locations in the USA [10,26], including Alaska [26,27], Washington [11] and southwestern states [12]. The shorter upper bill is typically narrower than the normal lower bill, similar to the discrepancy between the width of the premaxillary pad and the incisors on ruminants. Frequency of occurrence of bill, limb and feather malformations in bird populations is difficult to determine because they cause high mortality in pre- and post-fledglings.

Our observations of anomalies on mammals and birds also correspond in time with observations of significant increases in amphibian abnormalities with precipitous population declines connected to hormone disruption throughout the United States and Canada [28]. We directly observed the previously documented [29] decline in populations of Boreal Toad (Bufo boreas boreas) in Montana after 1994 and toads with hind limb malformations were noted in 1997 and 1998.

Multiple vertebrate species suddenly and simultaneously exhibiting similar developmental malformations is strong evidence for an environmental cause. Numerous studies of amphibians, birds and domestic mammals have shown that thyroid function is easily altered by exposure to a variety of chemicals [23]. Numerous manufactured compounds [30], many with the potential to disrupt the normal function of a variety of hormones $[23,25,28,31,32]$, are now present in the air, water and food. While disruption of sex hormones has been most studied, those chemicals that react with thyroid hormone, vitamin A receptors and retinoic acid levels may be even more damaging to fetal growth and health [28,31-33].

Signs previously described for equine foals [1-3,6] and other species [7,8,24,34] with congenital hypothyroidism were nearly identical to those we found on necropsied fawns of white-tailed deer and mule deer, and on elk calves, beef calves and newborn goats. Signs reported for bovines [35] include not only hypothyroid signs [36], but also hyperplasia of the thymus [37] and myocardial degeneration and necrosis of the left ventricle [38]. Additionally, thymic aplasia [38] was found in another ruminant, newborn sheep, with experimentally induced congenital hypothyroidism [24]. Many of the white-tailed deer fawns that had brachygnathia superior at birth also exhibited anomalous thymic and cardiac development, as well as other signs listed for congenital hypothyroidism [6,34], including contracted tendons and herniated umbilicus. Since 2007, we have also observed higher prevalence of underdeveloped and malformed male genitalia than we previously reported on RC $O$. virginianus fawns [16]. Anomalies of reproductive organs are now recognized as being a worldwide problem in an unprecedented number of wild vertebrate species [39]. While direct causes are difficult to identify $[9,40,41]$, the signs we found on wild and domestic species are consistent with those reported in experimental studies of congenital hypothyroidism in ungulate species $[6,7,24,37,38]$. 


\section{Why Did the Prevalence of Brachygnathia Superior Suddenly Increase?}

Many manufactured compounds and some heavy metals induce serious thyroid dysfunction at very low levels of exposure [9,23,25,31]. Chronic exposure to toxins that disrupt the function of or replace vital hormones can result in congenital hypothyroidism in newborn animals. At present, thyroid hormone-disrupting environmental chemicals are tested by measuring their ability to affect circulating levels of thyroid hormones [15]. However, essential thyroid hormone actions can be adversely affected without detectable changes to thyroid hormone levels as they are currently measured [31]. If specific environmental chemicals or their metabolites bind to fetal thyroid-hormone receptors, they can alter thyroid-hormone signaling responsible for normal development of fetuses [40,41]. Realistically, exposure to multiple hormone-disrupting compounds known to cause congenital hypothyroidism in vertebrates $[8,15,23,28,29,41,42]$ is now common to all organisms worldwide. The effects of such exposure on bone development of the skull and likely on the development of the brains of mammals and birds may be similar to the effects documented for dioxin exposure [43-46].

Multiple hormone disrupting toxins were found in snow, lake water, foliage and animals on the tops of mountains in USA national parks, with Glacier National Park, nearest to our study area, having the highest levels [30,47]. Such compounds are usually water soluble with a molecular structure that allows them to disrupt the normal activity of a variety of hormones. In addition, fetal exposure to both nitrates and nitriles have been shown to disrupt thyroid hormone function $[1,6,48]$ and nitrates are known to cross the placenta of rats, guinea pigs, pigs, and cattle [1].

One chemical that we suspect as being a factor in causing the sudden increase in congenital hypothyroidism in mammals and birds is chlorothalonil, a nitrile fungicide used on potatoes against potato blight. The amount of this fungicide used on potato fields in states up wind of western Montana approximately doubled in summer 1994 and continued to increase through 2000, decreasing somewhat after 2001 [49]. Similar polyhalogenated aromatic hydrocarbons (PHAHs) are known to cause multiple deformities and effects on multiple organs [50]. A recent study found exposure to chlorothalonil at one one-thousandth of levels commonly found in the environment resulted in mortality to tadpoles of all four frog species tested and endocrine disruption was indicated [51]. Low levels of toxins, including chlorothalonil [52], can be carried far from the application site in moist weather fronts [53]. Predictably [49,50], the increased prevalence of reproductive malformations corresponded to increased chlorothalonil use in states up wind of our area.

Another possible contributing factor is increasing use of neonicotinoid insecticides, registered for use in 1992 [54] and now one of the most widely used group of insecticides in the United States. Like chlorothalonil, winds can transport neonicotinoids over great distances from sites of application [55]. Two widely used neonicotinoids, imidacloprid and clothianidin, are acetylcholine receptor agonists and have been implicated in causing the die offs of domestic honeybee colonies $[55,56]$. Detrimental effects on honeybees were also found with exposure to chlorothalonil [57]. Neonicotinoids synergized with fungicides to increase the toxicity of the neonicotinoids to honey bees over 1,000 fold in lab tests [58]. Chlorothalonil and 
neonicotinoids in combination could also have a synergistic effect on developing mammals, as is strongly suggested by studies showing that nicotine and cyanide are responsible for disrupted fetal development in babies born to human mothers who smoke cigarettes [59].

A developing fetus is extremely susceptible to almost immeasurably small amounts of toxins crossing the placenta, potentially being affected by parts per trillion or even parts per quadrillion [59]. Many of the resultant disruptions of cellular development appear to be epigenetic and inheritable $[60,61]$. Pediatricians and the Ontario College of Family Physicians state that there is no safe level of pesticide exposure, especially to fetuses $[62,63]$. While the doctors were referring to human fetuses, the same is likely true for fetuses of other mammals.

\section{Conclusions}

Our observations of a previously unreported, extremely high prevalence of malformations, which are consistent with congenital hypothyroidism, on multiple wild ruminant species are critical to understanding the extent of serious wildlife and human health problems. Reproductive malformations [64-66] and many other health problems associated with endocrine disruption appear to be epidemic in human populations $[67,68]$. Signs of hypothyroidism in human neonates include not only skull and maxillary underdevelopment and neurological underdevelopment, but also vision and hearing problems, heart disease, underdeveloped external genitalia, and many other challenges $[15,23,69]$.

Our observations of an increasing prevalence of underdeveloped skull and upper facial bones in wild ruminants have corresponded to the simultaneous increase of reproductive malformations reported on males of many families of vertebrates $[16,38,70]$, which have been attributed to exposure to endocrine-disrupting toxins $[8,9,40,69-72]$. When exposed to one or a combination of environmental endocrinedisrupting toxins, pregnant females have been shown to experience adverse effects on cellular function $[40,67,68]$. As a consequence, their young may develop signs of thyroid-hormone disruption, one of the most common on ungulates being brachygnathia superior $[1,3,6,7]$. Thus, we suspect that the sudden, concurrent appearance of the high prevalence of brachygnathia superior and the other signs consistent with congenital hypothyroidism in multiple ruminant species strongly indicates widespread exposure of affected embryos and fetuses to multiple endocrinedisrupting environmental toxins.

\section{References}

Five "key references", selected by the authors, are marked below (Three recommended (•) and two highly recommended $(\bullet \bullet)$ papers $)$.

1. Allen, A.L., Doige, C.E., Fretz, P.B. \& Townsend, H.G.G. 1994. Hyperplasia of the thyroidgland and concurrent musculoskeletal deformities in western Canadian foals: Reexamination of a previously described syndrome. Can Vet J 35: 31-38.

PMid:8044756 
2. Allen, A.L., Fretz., P.B., Card, C.E. \& Doige, C.E. 1998. The effects of partial thyroidectomy on the development of the equine fetus. Equine Vet J 30: 53-59.

doi:10.1111/j.2042-3306.1998.tb04088.x

3. Allen, A.L. 1995. Hyperplasia of the thyroid gland and musculoskeletal deformities in two equine abortuses. Can Vet J 36: 234-236.

PMid:7600514

4. Schutte, J.G. \& Vandeningh, T.S.G.A.M. 1997. Microphthalmia, brachygnathia superior, and palatocheiloschisis in a foal associated with griseofulvin administration to the mare during early pregnancy. Vet Q 19: 58-60.

PMid:9225433

5. Kacar, C., Oezcan, K., Takci, I., Guerbulak, K., Oezen, H. \& Karaman, M. 2008. Diprosopus, craniorachischisis, arthrogryposis, and other associated anomalies in a stillborn lamb. J Vet Sci 9:429-431.

doi:10.4142/jvs.2008.9.4.429

6. Allen, A.L., Townsend, H.G. Doige, C.E. \& Fretz, P.B. 1996. A case-control study of the congenital hypothyroidism and dysmaturity syndrome of foals. Can Vet J 37: 349-358.

PMid:8689594

7. Soto-Blanco, B. \& Gorniak, S.L. 2004. Prenatal toxicity of cyanide in goats; a model for teratological studies in ruminants. Theriogenology 62:1012-1026.

doi:10.1016/j.theriogenology.2003.12.023

8. Selby, L.A., Menges, R.W., Houser, E.C., Flatt, R.E. \& Case, A.A. 1971. Outbreak of swine malformations associated with the wild black cherry Prunus serotina. Arch Environ Health 22: 496-501.

PMid:5102134

9. Colborn, T., vom Saal, F.S. \& Soto, A.M. 1993. Developmental effects of endrocrine-disrupting chemicals in wildlife and humans. Environ Health Perspect 101:378-384.

PMid:8080506

10. Rintoul, D.A. 2005. Beak deformity in a brown-headed cowbird, with notes on causes of beak deformities in birds. Kansas Ornithol Soc Bull 56: 29-32.

11. Blus, L.J., Melancon, M.J., Hoffman, D.J. \& Henny, C.J. 1998. Contaminants in eggs of colonial waterbirds and hepatic cytochrome P450 enzyme levels in pipped tern embryos. Washington State. Arch Environ Contam Toxicol 35: 492-497.

doi:10.1007/s002449900407

12. Sogge, M.K. \& Paxton, E.H. 2000. Summary of observed physical deformities in the willow flycatcher: 1996-2000. USGS Forest and Rangeland Ecosystem Science Center, Colorado Plateau Field Station report. 8 pp. [Technical Report]. sbsc.wr.usgs.gov/.../Reports/WIFL_ Deformity_Summary_Report_1996-2000b.pdf

13. Smits, J.E., Fernie, K.J., Bortolotti, G.R. \& Marchant, T.A. 2002. Thyroid hormone suppression and cell-mediated immunomodulation in American Kestrels (Falco sparcerius) exposed to PCBs. Arch. Environ. Contam. Toxicol. 43, 338-344.

doi:10.1007/s00244-002-1200-9

14. Porterfield, S.P. \& Hendrich, C.E. 1993. The role of thyroid hormones in prenatal and neonatal neurological development- current perspectives. Endocrine Reviews vol. 14 no. 1, 94-106.

doi:10.1210/edrv-14-1-94

15. Zoeller, R.T., Dowling, A.L.S., Hertzig, C.T.A., Iannacone, E.A., Gauger, K.J, \& Bansal, R. 2002. Thyroid hormone, brain development, and the environment. Environ Health Perspect 110 (S3): 355-361. http://www.jstor.org/stable/3455388 
16. Hoy, J.A., Hoy, R.D., Seba, D. \& Kerstetter, T.H. 2002. Genital abnormalities in white-tailed deer (Odocoileus virginianus) in west-central Montana: Pesticide exposure as a possible cause. J Environ Biol 23: 189-197.

PMid:12602857

17. Mosby, H.S. (ed.). 1963. Wildlife Investigational Techniques. Bethesda (MD): The Wildlife Society. p. 171-184.

18. Hoffmann, R.S. \& Pattie, D.L. 1968. A Guide to Montana Animals: Identification, Habitat, Distribution and Abundance. Missoula (MT): University of Montana. p. 61-62.

19. Barrett, M.W. \& Chalmers, G.A. 1975. Congenital anomalies in a neonatal white-tailed deer in Alberta. J Wildlife Dis 11: 497-501.

20. ๑๑ Ryel, L.A. 1963. The occurrence of certain anomalies in Michigan white-tailed deer. J Mammol 44: 79-98. doi: $10.2307 / 1377171$

21. Smits, B. \& Bubenik, G.A. 1990. Congenital osteopetrosis in white-tailed deer (Odocoileus virginianus). J Wildlife Dis 26: 567-571.

22. O'Gara, B. 1992. Preliminary report on field collections of white-tailed deer on the Lee Metcalf National Refuge. Stevensville (MT): Lee Metcalf National Wildlife Refuge, p. 1-30.

23. Colborn, T. 2002. Clues from wildlife to create an assay for thyroid system disruption. Environ Health Perspect 110: S3, 363-367. http://www.jstor.org/stable/3455389

24. Rae, M.T., Rhind, S.M., Kyle, C.E., Miller, D.W. \& Brooks, A.N. 2002. Maternal undernutrition alters triiodothryonine concentrations and pituitary response to GnRH in fetal sheep. J Endocrinol 173: 449-455.

doi: $10.1677 /$ joe. 0.1730449

25. Porter, W.P., Green, S.M., Debbink, N.L., \& Carlson, I. 1993. Groundwater pesticides: Interactive effects of low concentrations of carbamates Aldicarb and Methamyl and the triazine Metribuzin on thyroxine and somatotropin levels in white rats. J Toxicol Environ Health 40: 15-34. doi:10.1080/15287399309531773

26. Handel, C.M., Pajot, L.M., Matsuoka, S.M., Van Hemert, C., Terenzi, J. Talbot, S.L., Mulcahy, D.M., Meteyer, C.U. \& Trust, K.A. 2010. Epizootic of beak deformities among wild birds in Alaska: an emerging disease in North America? Auk 127: 882-898.

27. Van Hemert, C. \& Handel, C.M. 2010. Beak deformities in northwestern crows: Evidence of a multispecies epizootic. Auk 127: 746-751.

28. Ouellet, M., Bonin, J., Rodrique, J., DesGranges, J-L. \&. Lair, S. 1997. Hindlimb deformities (Ectromelia, Ectrodactyly) in free-living anurans from agricultural habitats. J Wildlife Dis 33: 95-104.

29. Biek, R., Funk, W.C., Maxell, B.A. \& Mills, L.S. 2002. What is missing in amphibian decline research: Insights from ecological sensitivity analysis. Cons Biol 16: 728-734.

doi:10.1046/j.1523-1739.2002.00433.x

30. - Landers, D.H., Simonich, S., Jaffe, D., Geiser, L., Campbell, D.H., Schwindt, A., Schreck, C., Kent, M., Hafner, W., Taylor, H.E., Hageman, K., Usenko, S., Ackerman, L., Schriau, J., Rose, N., Blett, T., \& Erway, M.M. 2010. The Western Airborne Contaminant Assessment Project (WACAP): An Interdisciplinary Evaluation of the Impacts of Airborne Contaminants in Western US National Parks. Environ Sci Technol 44: 855-859.

doi:10.1021/es901866e

31. Miller, M.D., Crofton, K.M., Rice, D.C. \& Zoeller, R.T. 2009. Thyroid-Disrupting Chemicals: Interpreting Upstream Biomarkers of Adverse Outcomes. Environ Health Perspect 117: 10331041.

doi:10.1289/ehp. 0800247 
32. Rolland, R. R. 2000. A review of chemically-induced alterations in thyroid and vitamin A status from field studies of wildlife and fish. J Wildlife Dis 36:15-35.

33. Dallegrave, E., Mantese, F.D., Coelho, R.S., Pereira, J.D., Dalsenter P.R., \& Augusto Langeloh, A. 2003. The teratogenic potential of the herbicide glyphosate-Roundup ${ }^{\circledR}$ in Wistar rats. Toxicol Letters 142: 45-52.

doi:10.1016/S0378-4274(02)00483-6

34. Singh, J.L., Sharma, M.C., Kumar, M., Varshney, V.P., Ahmal, A.H. \& Prasa, S. 2003. Clinicobiochemical profile and therapeutic management of congenital goiter in kids. Indian J Vet Med 23: 83-87.

35. Brenner, J., Elad, D. \& Malkinson, M. 2008. Management of 21 emerging livestock diseases by the Israel Veterinary Services. Israel J Vet Med 63: 102-115.

36. Smyth, J.A., Goodall, E.A., McCoy, M.A. \& Ellis, W.A. 1996. Stillbirth/perinatal weak calf syndrome: A study of calves with an abnormal thyroid gland. Vet Rec 139: 11-16.

37. Takasu, M., Shirota, K., Ohba, Y., Nishii, N., Murase, T., Miyazawa, K. \& Kitagawa, H. 2008. Thymic hypoplasia in Japanese black calves with stillbirth/perinatal Weak Calf Syndrome. J Vet Med Sci 70: 1173-1177. doi:10.1292/jvms.70.1173

38. Murray, R.D., Williams, A.J. \& Sheldon, I.M. 2008. Field investigation of perinatal mortality in Friesian cattle associated with myocardial degeneration and necrosis. Reprod Domestic Anim 43: 339-34. doi:10.1111/j.1439-0531.2007.00911.x

39. Lyons, G. 2008. Effects of pollutants on the reproductive health of male vertebrate wildlife males under threat. CHEMTrust. www.chemtrust.org.uk. Cited 5 May 2011.

40. Zoeller, R.T., Bansal, R. \& Parris, C. 2005. Bisphenol-A, an environmental contaminant that acts as a thyroid hormone receptor antagonist in vitro, increases serum thyroxine, and alters RC3/Neurogranin expression in the developing rat brain. Endocrinology 146: 607-612. doi:10.1210/en.2004-1018

41. Brouwer, A., Morse, D.C., Lans, M.C., Schuur, A.G., Murk, A.J., Klasson-Wehler, E., Bergman, A. \& Visser, T.J. 1998. Interactions of persistent environmental organohalogens with the thyroid hormone system: Mechanism and possible consequences for animal and human health. Toxicol Ind Health vol. 14 no. 1-2 59-84.

doi:10.1177/074823379801400107

42. Kashiwagi, K., Furuno, N., Kitamura, S., Ohta, S., Sugihara, K., Utsumi, K., Hanada, H., Taniguchi, K., Suzuki, K. \& Kashiwagi, A. 2009. Disruption of thyroid hormone function by environmental pollutants. J Health Sci 55: 147-160.

doi: $10.1248 /$ jhs. 55.147

43. Henshel, D.S. 1998. Developmental and neurotoxic effects of dioxin and dioxin-like compounds on domestic and wild avian species. Environ Toxicol Chem 17: 88-98.

doi:10.1002/etc.5620170111

44. Henshel, D.S., Hehn, B., Wagey, R., Vo, M., \& Steeves, J.D. 1997. The relative sensitivity of chicken embryos to yolk or aircell - injected 2,3,7,8 - tetrachlorodibenzo-p-dioxin. Environ Toxicol Chem 16: 725-732.

45. Henshel, D.S., Martin, J.W., \& DeWitt, J.C. 1997. Brain asymmetry as a potential biomarker for developmental TCDD intoxication: a dose-response study. Environ Health Perspect 105: 718-725. 
46. Henshel, D.S., Vo, M.T., Hehn, B., \& Steeves, J.D. 1993. A short-term test for dioxin teratogenicity using chicken embryos. In: Hughes, J., et al. (eds.), ASTM STP \#1173: Second Symposium on Environmental Toxicology and Risk Assessment. American Society for Testing and Materials (ASTM), Philadelphia, p. 159-174.

47. Usenko, S., Simonich, S.L.M., Hageman, K.J., Schrlau, J.E., Geiser, L., Campbell, D.H., Appleby, P.G., Landers, D.H. 2010. Sources and Deposition of Polycyclic Aromatic Hydrocarbons to Western U.S. National Parks. Environ Sci Technol 44 (12): 4512-4518. doi:10.1021/es903844n

48. Saillenfait, A.M. \& Sabate, J.P. 2000. Comparative developmental toxicities of aliphatic nitriles: in vivo and in vitro observations. Toxicol Appl Pharmacol 163: 149-63.

49. National Agricultural Statistics Service, Agricultural Chemical Use Database. http://www.pestmanagement.info/nass/app_usage.cfm. Cited 6 May 2011.

50. Greenlee AR, Ellis TM, Berg RL. 2004. Low-dose agrochemicals and lawn-care pesticides induce developmental toxicity in murine preimplantation embryos. Environ Health Perspect 112: 703-709.

51. McMahon, T., Halstead, N., Johnson, S., Raffel, T.R., Romansic, J.M., Crumrine, P.W., Boughton, R.K., Martin, L.B. and Rohr, J.R. 2011. The fungicide chlorothalonil is nonlinearly associated with corticosterone levels, immunity, and mortality in amphibians. Environ Health Perspect.

doi:10.1289/ehp.1002956

52. Chernyak, S.M., Rice, C.P. \& McConnell, L.L. 1996. Evidence of currently used pesticides in air, ice, fog, seawater and surface microlayer in the Bering and Chukchi seas. Mar Pollut Bull 32: 410-419. doi:10.1016/0025-326X(95)00216-A

53. Seba, D.B. \& Prospero, J.M. 1971. Pesticides in the lower atmosphere of the northern equatorial Atlantic Ocean. Atmos Environ 5: 1043-1050.

doi:10.1016/0004-6981(71)90004-7

54. Frazier, M. T., C. Mullin, J. Frazier. 2008. What have pesticides got to do with it? Amer Bee J 148: 521-523.

55. Nauen, R., Ebbinghaus-Kintscher, U. \& Schmuck, R. 2001. Toxicity and nicotinic acetylcholine receptor interaction of imidacloprid and its metabolites in Apis mellifera (Hymenoptera: Apidae). Pest Manag Sci 57: 577-586.

56. Guide to pesticide modes of action http://www.dropdata.org/RPU/. Cited 6 May 2011.

57. USDA Colony Collapse Disorder Progress Report. 2010. www.ars.usda.gov/is/br/ccd/ ccdprogressreport2010.pdf. Cited 6 May 2011.

58. Iwasa, T., Motoyama N., Ambrose, J. T. \& Roe, R.M. 2004. Mechanism for the differential toxicity of neonicotinoid insecticides in the honeybee, Apis mellifera. Crop Prot 23:371- 378.

59. Walker, S.K., Hartwich, K.M. \& Robinson, J.S. 2000. Long-term effects on offspring of exposure to oocytes and embryos to chemical and physical agents. Human Reprod Update 6:564-577.

60. Waterland, R.A. \& Jirtle, R.L. 2003. "Transposable elements: targets for early nutritional effects on epigenetic gene regulation. Mol Cell Biol 23: 5293-5300.

doi:10.1128/MCB.23.15.5293-5300.2003

61. Anway, M., Cupp, A., Uzumcu, M. \& Skinner, M. 2005. Epigenetic transgenerational actions of endocrine disruptors and male fertility. Science 308: 1466-1469.

62. Weiss, B., Amler, S. \& Amler, R. W. 2004. Pesticides. Amer Acad Ped 113: 1030-1036. 
63. Ontario College of Family Physicians. 2004. Child Health and the Environment. Available via DIALOG. http://www.ocfp.on.ca/English/OCFP/Communications/Publications/default. asp?s=1\#EnvironmentHealth. Cited 6 May 2011.

64. Swan, S.H., Main, K.M., Liu, F., Stewart, S.L., Kruse, R.L., Calafat, A.M., Mao, C.S., Redmon, J.B., Ternand, C.L., Sullivan, S., Teague, J.L. \& the Study for Future Families Research Team. 2005. Decrease in anogenital distance among male infants with prenatal phthalate exposure. Environ Health Perspect 113: 1056-1061.

doi:10.1289/ehp. 8100

65. Sharpe, R.M. 1993. Hormones and testis development and the possible adverse effects of environmental chemicals. Chem Eng News 71: 9-12.

66. Sharpe, R.M. 2006. Pathways of endocrine disruption during male sexual differentiation and masculinization. Best Pract Res Cl En 20: 91-110.

doi:10.1016/j.beem.2005.09.005

67. Rapp, D.J. 2003. Our Toxic World A Wake Up Call. Buffalo (NY): Environmental Medical Research Foundation. p. 159-202.

68. Colborn T. 2004. Neurodevelopment and Endocrine Disruption. Environ Health Perspect 112(9): 944-949.

doi:10.1289/ehp.6601

69. Diamanti-Kandarakis, E., Bourguignon, J.-P., Giudice, L.C., Hauser, R., Prins, G.S., Soto, A.M., Zoeller, R.T. \& Gore, A.C. 2009. Endocrine-disrupting chemicals: An Endocrine Society scientific statement. Endocr Rev 30: 293 - 342.

doi:10.1210/er.2009-0002

70. Veeramachaneni, D.N.R., Amann, R.P., \& Jacobson, J.P. 2006. Testis and antler dysgenesis in Sitka black-tailed deer on Kodiak Island, Alaska: sequela of environmental endocrine disruption? Environ Health Perspect 114(S1):51-59.

doi:10.1289/ehp. 8052

71. Hayes, T., Haston, K., Tsui, M., Hoang, A., Haeffele, C. \& Vonk, A. 2003. Atrazine-induced hermaphroditism at $0.1 \mathrm{ppb}$ in American Leopard frog (Rana pipiens): Laboratory and field evidence. Environ Health Perspect 111:568-575.

doi:10.1289/ehp.5932

72. Hayes, T.B., Khoury, V., Narayan, A., Nazir, M., Park, A., Brown, T., Adame, L., Chan, E., Buchholz, D., Stueve, T. \& Gallipeau, S. 2010. Atrazine induces complete feminization and chemical castration in male African clawed frogs (Xenopus laevis). Proc Natl Acad Sci U S A. 107: 4612-4617.

doi:10.1073/pnas.0909519107 